\title{
HUMOR AND LINGUISTIC VARIATION IN BIENVENUE CHEZ LES CH'TIS: THE CATALAN AND SPANISH CASE
}

\author{
Eva Garcia-Pinos \\ eva.garcia@upf.edu \\ Universitat Pompeu Fabra
}

\begin{abstract}
This paper aims to analyze the function of linguistic variation in a humoristic audiovisual text within the translation context. Bienvenue chez les Ch'tis (2008) has been chosen as object of study. In this French film both humor and linguistic variation are key elements of the plot. Dubbing and subtitles have been analyzed and the target languages are Catalan and Castilian Spanish. This article demonstrates that a constructed dialect has been used as a strategy in both target texts.
\end{abstract}

\section{Resum}

Aquest treball pretén analitzar la funció de la variació lingüística en un text humorística audiovisual en el context de la traducció. Com a objecte d'estudi s'ha escollit la pel-lícula francesa Bienvenue chez les Ch'tis (2008), en què tant l'humor com la variació lingüística són elements clau de l'argument. Les modalitats analitzades són doblatge i subtitulació i les llengües meta català i castellà. Aquest article demostra que en tots dos textos meta l'estratègia de traducció aplicada ha estat la creació d'una varietat lingüística fictícia.

Keywords: Humor. Linguistic Variation. Audiovisual Translation. Dubbing. Subtitles.

Paraules clau: Humor. Variació lingüística. Traducció audiovisual. Doblatge. Subtitulació. 
Manuscript received on June 29, 2016 and accepted for publication on October 31, 2016.

Para enlazar con este artículo / To link to this article:

http://dx.doi.org/10.6035/MonTI.2017.9.6

Para citar este artículo / To cite this article:

GarCiA-Pinos, Eva. (2017) "Humor and Linguistic Variation in Bienvenue chez les Ch'tis: The Catalan and Spanish case." In: Martínez Sierra, Juan José \& Patrick Zabalbeascoa Terran (eds.) 2017. The Translation of Humour / La traducción del humor. MonTI 9, pp. 149-180. 


\section{Introduction}

Translating humor in texts, either written or audiovisual, has been a matter of discussion due to the multiple ways of creating humor in STs (source texts) and what they entail in TTs (target texts). Nevertheless, studies in this area are relatively new, especially those related to audiovisual texts.

Humor as a consequence of linguistic variation is present in literature and cinema. Recently, this has been very popular in films and TV series and several examples can be found. Linguistic variation is usually only a part of the story line but it sometimes becomes the center of the plot.

This article focuses on the translation, both subtitles and dubbing, of Bienvenue chez les Ch'tis (2008) in Catalan and Spanish, which had a great reception in France as well as in Spain. Its aims are to analyze the TTs and identify which translation strategies have been used in order to deal with the linguistic variation of the ST that represents the main plot of the film and if an equivalent effect of funniness has been reached.

The analysis has been structured according to modalities, languages and the classification of language levels by Chaume (2004: 170-182). ${ }^{1}$ With regard to the methodology, the ST has been examined alongside the TTs focusing in the STs' variation and in the TTs' solutions. The corpus chosen for this paper is formed by the content in the DVD that was published in Spain in 2009 by Cameo Media S.L., which includes the original version in French, and dubbing and subtitling in Catalan and Spanish. ${ }^{2}$ Subtitles in French ${ }^{3}$ are not included; therefore, the French version of the DVD has also been used.

The film as a whole has been used for the text analysis. Dialogs in the dubbed versions have been transcribed from the DVD audio without the translated script. The ST has been transcribed using the script (Reutner 2013) as support. The subtitles have also been transcribed.

1. Prosodic, morphological, syntactic and lexical-semantic.

2. The Spanish dubbing was carried out by Alicia Aguirre de Cárcer, the subtitles by Lola Núnez-Flores. No further information about the Catalan TTs has been found.

3. These are for hearing-impaired people. 


\section{About Bienvenue chez les Ch'tis}

Bienvenue chez les Ch'tis is a film directed by Dany Boon (artistic name of Dany Hamidou). It was released in 2008 in France and in 2009 in Spain, entitled Bienvenidos al Norte in Spanish and Benvinguts al Nord in Catalan. According to Allociné it broke nearly every box office record in France and it was also very popular in Spain. Dany Boon is also one of the co-writers and performs one of the main roles. The film is also starred by Kad Merad as Philippe Abrams.

The plot must be summarized to clarify the reason that makes this audiovisual text worth studying from a perspective of humor and linguistic variation. A postal clerk (Philippe Abrams) is transferred from his office in the South of France to Bergues, in the North, as an administrative punishment. He talks to his wife's uncle, who has been there and who gives some pieces of advice. Basically he talks about stereotypes from the people and the customs or traditions in the North, e.g. they speak a strange and complicated variety that nobody is able to understand. Abrams goes there and at first he struggles a bit to adapt, but he meets certain people whom he befriends.

The linguistic variation plays a central role in the plot, because there are a huge number of situations focused on linguistic issues, such as metalinguistic explanations, misunderstandings and puns.

\section{Linguistic variation: Chti}

According to UNESCO, Chti is more commonly known as Picard but it also has other names, such as Patois, Ch'ti or Rouchi. It is spoken in Picardie, Nord-Pas de Calais and the area between Tournai and Mons, in the Western region of Hainaut, in Belgium. Since it is not clear if Chti is a language or a dialect, in this paper it is going to be considered as a dialect, according to the status that it has in the film.

Große (2010: 124) points out that the name "Chti" has recently become more popular. The historical origin of this name is specially documented in Fernand Carton's works. ${ }^{4}$ This name was not found by researchers working on dialects in France until 1914 (Carton 2006: 139); and since then some other derived names, such as "Chtimi", "Timi", "S'timi", "Chetimi", "Ch'timie" or "Chtismis", have also been noticed.

It is also important to say that French spoken in Nord-Picardie is called "Chti" in the North and "Picard" in the South (Große 2010: 126).

4. As Große points out, see Bril (2008) and Dawson (2008) for more information. 
In her paper, Große (2010: 126-132) summarizes which features have been used in the constructed orality of the film. Chti pronunciation shifts appear at both the linguistic and the metalinguistic level. Regarding the metalinguistic level, it is Philippe Abrams' wife's uncle who talks about the most recognizable features, which are:

- Replacing [a] with [o].

- Replacing [S] with [k].

- Replacing [s] with [J].

The latter one is the feature that Große describes as more frequently used to characterize Chti in the film (2010: 128). The vocalic shift is used to a small degree in the film because it appears to be less regular and therefore this shift is less recognizable as a feature of Chti. Große (2010: 128) establishes that the vocal shift in the film is not only replacing [a] with [o], but also with [œ], but it is not included in the metalinguistic level. Another pronunciation shift that is not explained in the metalinguistic level is the palatalization of [1] and [n] in last position (Große 2010: 128; Carton 1990: 608-609).

In relation to the lexical level, several words recognized as Chti have been used in the film. Große states that lexical differences are easier to appreciate when in contact with different languages or different varieties and therefore the funniness of many scenes in the film is based on this (2010: 129).

In short, what characterizes Chti in the film according to Große (2010: 131-132) is:

- The inhabitants of Bergues tend to speak Chti in almost any situation, but there are different varieties (e.g. Antoine's mother speaks a local variety and Annabelle speaks a variety very close to regional French). ${ }^{5}$

- Chti speakers also show their command of standard and regional French.

- The line of demarcation between Chti speakers and standard French speakers is created with certain typical pronunciation features and certain characteristic words.

- Metalinguistic explanations are used as a strategy to help understand the film.

5. Carton (1990: 610) establishes the following classification: common French, regional French, dialectal French (local) and country French. 
- Chti speakers shift to another variety when comprehension problems arise. They generally use standard French when explaining a cultural or linguistic feature.

- Philippe accepts his role as student and makes an effort to learn and speak Chti in order to become fully integrated and be accepted. His learning process is characterized by great flexibility and lack of intuition and spontaneity.

- This linguistic reality shows how being integrated into a community relies on linguistic integration.

- What the film does not generally transmit is the dynamic contact situations and evaluation of communicative and discursive situations for the selection of the proper variety or varieties.

- The film is a sort of introduction to linguistic and cultural variation.

In addition, it should not be forgotten that linguistic variation is used here in a constructed orality context, ${ }^{6}$ which means that the language is being imitated and the main Chti features have been selected for this aim.

\section{Theoretical Framework}

\subsection{Linguistic Variation and Translation}

The first theories of linguistic variation were proposed by Halliday, McIntosh \& Strevens (1964), Catford (1965), and Gregory (1967). Halliday, McIntosh \& Strevens (1964: 77) define language variation as a continuum and subdivide it into varieties according to users (dialect) and varieties according to use (register). Catford (1965: 85), however, classifies the varieties according to whether they are more or less permanent (idiolect and dialect) and more or less transient (register, style and mode). Gregory (1967: 181) classifies variation according to situational categories (individual, temporal provenance, geographical provenance, social provenance and range of intelligibility) and according to contextual categories (idiolect, temporal dialect, geographical dialect, social dialect and standard/non standard dialect).

Later, Hatim and Mason (1990: 39) present a classification for translation based on the model by Halliday, McIntosh \& Strevens (1964). In their model, variation is classified according to use (register), which includes field, mode and tenor; and according to user (dialect), which includes geolectal, cronolectal, social, (non)standard and idiolectal variation.

6. See Brumme (2012) for more information. 
Rabadán (1991) sorts linguistic variation into geographic, diachronic or social categories. ${ }^{7}$ Muñoz (1995) classifies the variation similarly: social variation, geographic dialects, temporal dialects, social dialects, non-standard, social class, education, race, ethnic group, sex, idiolect and variation according to use (register). In his work, which is one of the most extensive ones, Mayoral (1999) reviews a huge number of approaches of different fields (linguistic, sociolinguistic, translation and ideological studies). Finally, Tello (2011) carefully overviews different approaches, classifications and strategies in order to analyze a whole corpus of literary texts.

Regarding Hatim and Mason's model (1990), in linguistic variation according to user (dialects), geolectal variation is bound to the geographical provenance of the speaker, but Hatim and Mason (1990: 40) claim there are erroneous concepts based on the idea that a variety can be delimited by borders and geolectal variation has the same status no matter where it is spoken; consequently, such notions can affect a translator's decisions negatively.

Concerning geolectal variation detection, one of the most easily recognizable features is accent (1990: 40). Hatim and Mason make us aware of the risk of translating this type of dialect from the source language (SL) into a dialect in the target language (TL) as an equivalent because of unwanted connotations that can be added to the TT (1990: 41). According to authors such as Catford (1965: 87-88), geolectal variation is very often associated with sociolectal variation in languages like English.

They draw special attention to the fact that there is no judgment about the linguistic value related to the standard/non-standard concept, but to intelligibility, even though it is also related to prestige. It must be taken into account that, when a non-standard dialect is used in a standard dialect context, this is aimed at identifying the non-standard dialect with the values of the social group to which it refers (Hatim \& Mason 1990: 43).

With regard to translation strategies, on the one hand, Marco (2002: 81) presents a scheme in which several binary splits are presented:

7. She also talks about audiovisual translation, which is categorized as a type of subordinated translation as it depends on the images. 


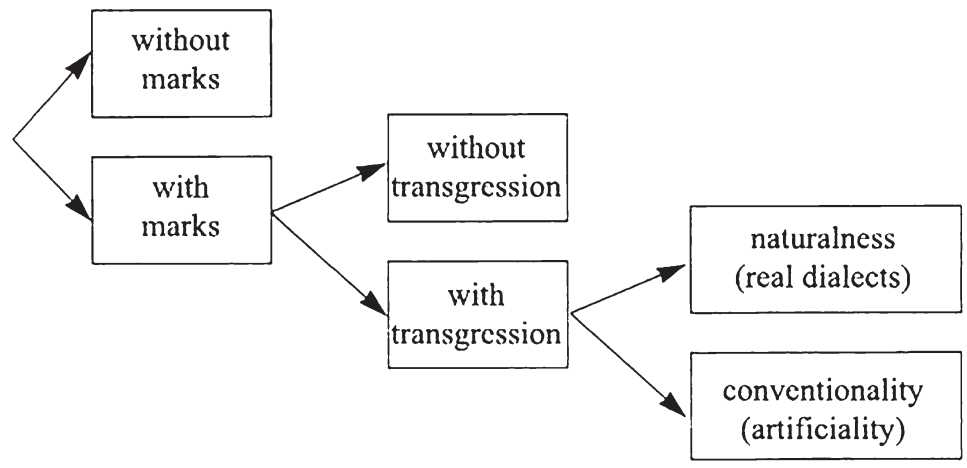

Figure 1. Marco's (2002: 81) scheme

Following an option that includes "with", another option must be taken. In this scheme the first binary split refers to neutralizing (standardize) or marking the TT in some way (e.g. recreating the linguistic variation of the ST). If marking the text is decided, then the binary split may be transgressing the linguistic norm (orthography, grammatical, lexical, using incorrect structures or non-standard vocabulary) or not. Finally, if transgression is chosen, then the binary split is naturalness (choosing features of a real dialect, which refer to dialectal prototypes of the reader's culture) or conventionality (using a constructed dialect).

On the other hand, Czennia (2004: 509-510) lists a total of nine translation strategies related to linguistic variation in ST that she identifies in her research.

1) Replacing geolectal linguistic variation marks in ST with geolectal linguistic variation marks of the TL.

2) Replacing geolectal linguistic variation marks in ST with a combination of typical features of different geolectal varieties of the TL ("mixture of dialects" or "constructed dialect").

3) Replacing geolectal linguistic variation marks in ST with sociolectal linguistic variation marks of the TL.

4) Replacing geolectal linguistic variation marks in ST with idiolectal linguistic variation marks (e.g. individual linguistic features) or register marks (e.g. according to age, gender or work sphere) on the TT.

5) Replacing geolectal linguistic variation marks with standard variation without renouncing other marks as pragmatic, morphosyntactic or lexical-stylistic of the TL orality. 
6) Replacing geolectal linguistic variation marks with a variety from the TL that fits the language of communicative distance, both in the standard conception and the written conception.

7) Omitting geolectal elements.

8) Replacing geolectal linguistic variation marks with a characteristic written variety of the TL that balances out the omitted information adding information (e.g. with verba dicendi that focus on the character's dialectal discourse without using non-standard elements).

9) Combining strategies 1, 2, 3 or 4 with 6 (this involves the exceptional use of geolectal, sociolectal, idolectal or register marks, e.g. when the character first appears, and then applying strategy 6).

The restrictions that are characteristic of audiovisual texts in relation to translation strategies must be taken into account. Therefore, strategies 8 and 9 can only be used in written texts.

\subsection{Humor and audiovisual translation}

Bienvenue chez les Chtis is a comedy film in which the plot revolves around linguistic variation. In a high number of scenes funniness is created through the use of language. Martínez Sierra (2015) mentions Fuentes (2001: 17), who distinguishes four types of humor - verbal, visual, graphic and audiovisual. Whitman (1992: 138) makes us aware of the inevitable bond between humor and culture, ${ }^{8}$ as in Bienvenue chez les Ch'tis.

When it comes to translating this film, as it is a complex audiovisual text, Zabalbeascoa's priorities and restrictions model ( $\mathrm{P}+\mathrm{R})$ (2001) should be taken into account. According to this model,${ }^{9}$ the highest range priority would be to maintain humor and we agree with the restrictions that Martínez Sierra (2015) establishes in dubbing humoristic texts, which consist of linguistic, cultural and synchrony problems. In the subtitling modality, they would be linguistic, cultural and subtitle-specific (i.e. length). The fact that the source text utterances are audible in the subtitled modality can also be regarded as a restriction.

The case that is being analyzed in this paper is also complex. In the film, humor can not only be observed in some specific scenes (in which jokes, puns or linguistic misunderstandings are present) but in the way Chti characters speak (amplified).

8. Laurian (1992), Nash (1985), Martínez Sierra (2008), Zabalbeascoa (1996).

9. We are only focusing briefly on priorities and restrictions because of the article extension. 
In addition, even though humor was only present in certain parts, as the funniness is related to linguistic variation in some scenes, it is a constant feature of Chti characters (it would be very unusual for their speech to only be marked in some scenes $)^{10}$ and it must be continuous in the whole film.

Martínez Sierra (2015) refers to Manini (1996: 173), who claims the need to distinguish between translating for "the stage and for the page", and relates "the stage" with audiovisual translation to make us aware of the intrinsic restrictions of dubbing and subtitling modalities. This assertion is meaningful in relation to translation strategies and audiovisual translation, because neither footnote nor verba dicendi are feasible ways to deal with humor and linguistic variation in a case of study like this one.

Regarding credibility, Zabalbeascoa (2008: 171) claims that the most important aspect in a dubbed audiovisual text is a perfect synchrony with the lip movements. He also refers to what Chaume (2003: 102) adds to the notion of credibility, claiming that it is constructed by synchrony and translations and the quality of dubbing voices. Zabalbeascoa also states that using dialects in audiovisual texts, both original and dubbed, is always a polemic topic and that there are almost as many options as spectators. Therefore the aim of audiovisual translation should be to create and to keep the constructed reality instead of trying to emulate reality, as it is not a real situation, but a constructed orality (2008: 175).

\section{Dubbing}

\subsection{Catalan}

\subsubsection{Prosodic Level}

Three different types of phonetic shifts can be found in the Catalan dubbing - vocalic, consonantal and elisions, which have been applied somewhat systematically. In relation to the vocalic shifts, this is the most systematic one in Catalan dubbing and it is also the one that is most regularly applied. One of the most frequently used shifts is to replace [ai] for [i] in certain verbs like deixar ('to let') and queixar-se ('to complain').

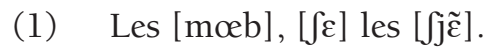

Es veu que no els van [difá]. (22:45)

10. Even though it is possible for a character to imitate a specific regional accent when telling jokes. 
(2) J'ai jamais dit [ $\mathrm{Ja}]$.

No he dit pa re, de [kifá]. (22:54)

Another vocalic shift has also been detected in some other verbs. It consists in replacing [at'] for [ai] in faig ('I make'), conjugated verb form of fer ('to make').

(3) Non, je rigole pas du tout.

No [fái] broma de re, jo. (27:17)

(4) Ah moi aussi je peux frimer aussi avec ma vélo-là.

Mira, jo també ho [fái] amb la bici. (37:06)

Some vocalic shifts are only present in one word, as can be seen in com ('what'), whereby [o] is replaced by [u].

(5) - $[$ me jjø] Vasseur, comment [ [a] va ce matin?

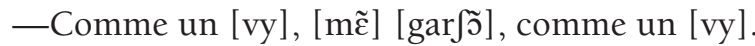

-Bon dia, 'nyor Vasseur, [kum] anem? (32:48)

- [kum] un vell, ves, [kum] un vell. (32:49)

This shift could be the result of articulatory synchrony, which is an important issue in dubbing. [kum] is similar to comme pronounced as [ky], the Chti way, instead of $[\mathrm{kom}]$.

Consonant shifts are the most frequent phonetic shifts in Catalan dubbing. One of them has a higher impact than others. As in the ST, [s] has been replaced by [S] emulating the most iconic and audible feature of Chti. ${ }^{11}$ This sound also exists in Catalan but not in Spanish.

This shift has usually been applied at the beginning and at the end of some words like sí ('yes'), és ('he/she/it is') or soroll ('noise').

(6) - $[\mathrm{me} \mathrm{j} ø]$ Bailleul ?

-Ouais, [Se] [mi].

-Senyor Bailleul?

-[jí], jo mateix. (20:59)

(7) J'vous ai reconnu à vot' plaque qu'est treize. [ifi] [ $\mathrm{Se}]$ cinquante-neuf.

[éf] q'[ai] vist la matrícula, [kef] tretze, i no [Jinkwəntənów]. (21:08)

11. Since this consonantal shift is so iconic, it is also present in the Spanish dubbing and subtitles (see 5.2.1. and 6.2.1). 
(8) Faut pas qu'on [fase] trop de bruit.

No fem [pá] gaire [xuróó]. (24:24)

This shift is not systematic, a whole [s] replacement may complicate the understanding too much. This may be a reason for the actual replacements. The phoneme [ $[$ ] can also be observed replacing [k] in cul ('bottom') even though Chti characters replace this sound with $[\mathfrak{t}]$ :

(9) J'ai mal à $[\mathrm{m} \tilde{\varepsilon}][\mathrm{t} y \mathrm{y}]$.

Només [mi] fa mal el [júl] i prou. (21:24)

(10) Je suis tombé sur [mẽ] [tyy].

[éf] [kí] caigut de [Júl]. (21:24)

(11) "Le [tyy] ?" Voilà, c'est pas [terib] comme vous parlez. Vous voulez pas qu'on aille montrer [vot] mâchoire à un médecin ? "De [fúl]"? Si vostè no parla bé... Vol dir que no vol que el vegi un metge? (21:27)

This last example of shift contributes to the funniness, especially since it is the key word for humor in the conversation in the first scene in which Chti and standard French come into contact - when Philippe and Antoine first meet. The word cul exists in both French ([ky]) and Catalan ([cúl]).

Finally, another minor shift has been observed: replacing [ $\left.\int\right]$ with [s] in això ('this') and així ('this way'), these forms have also been marked with elisions. They are widely used in some Catalan varieties.

(12) Ouais, les [jjẽ $],[\mathrm{je}][\mathrm{Ja}]$.

Sí, [ðifá], [əsó], [əsó]. (32:09)

(13) On $[\mathrm{e}] \mathrm{chez}$ ma mère, $[\mathrm{i} \mathrm{j} \mathrm{i}]$.

No, [só] [éf] casa ma mare. (24:10)

(14) Respirez par [œl] bouche, [ $\left.\int \mathrm{a}\right]$ va aérer.

Respiri [pélə] boca, [sí] [Jjjrəzará]. (29:10)

Regarding the elisions, they play an important role both in the ST and the TT as they tend to be an important part of orality in both languages. Deleting [ə] at the beginning of some conjugated verb forms as anar ('to go'), agafar ('to take'), agradar ('to like'), enamorar ('to fall in love') or ensenyar ('to teach') is one of the most noticeable elisions:

(15) Ah ben. Faut vite aller se coucher, alors. [Se] là-haut. Ah, donques [ném] directe al llit. [e]] dalt. (23:53) 
(16) Au fond, y a la [Jal] de bains, y a tout ce qu'il faut.

I al fons hi ha [áulə] bany, [gáfi] el que convingui. (24:16)

(17) Parce qu'il faut pas me raconter des carabistoules, hein.

No [mi] [gráðə] que [mi] alci ningú la camisa. (33:21)

(18) T'[avo] peur que j'tombe amoureux ?

No [Jé] de què tenia por, de que [mi] '[nəmurés]? (37:28)

(19) Ben, alors, on t'as pas appris à dire $\left[\operatorname{m\varepsilon R} \int \mathrm{i}\right][\mathrm{d} \tilde{\varepsilon}][\mathrm{t} \tilde{\varepsilon}]$ pays ?

Vaja, [kəKá] baix no li han [səyát] a dir gràcies, o què passa?

$(37: 42)$

Other types of elision have been observed. They appear at the beginning or within some words in particular cases:

(20) [ [e] juste au-dessus, votre logement de [fõk $\left.\int j \tilde{z}\right]$, au d'sus [dœl] poste.

[éf] just a [〔óßrə] l'oficina, [Éulə] xeu pis, [noðictó]. (21:42)

(21) [me jjø] Abrams, [éf] l'heure. [me $j ø]$ Abrams, faut vous réveiller, hein ?

Escolti, [kéf] l'hora. [クó] Abrams, [ á] de llevar. (25:55)

(22) $[e ́ f][m \tilde{\varepsilon}]$ nouveau patron, quand même.

[kés] [Éulə] nou [ðictó], dona. (26:55)

The examples above show internal and contact constructed elisions involving words such as senyor ('sir') and director both pronounced [sənó] and [dirəktó] in central Catalan. These words have become [yó], [ðictó] and [noðictó] in the Catalan dubbing.

\subsubsection{Morphological Level}

Personal pronouns present the highest number of variation in the TT (23-25).

(23) J'parle ch'timi, quo.

Parlo xetimí, [عuzú]. (21:37)

(24) Voilà, [ et] [ifi], m’baraque.

[éf] aquí on [bíc] [عuzú]. (23:29)

(25) Marié, [mi]? Y a pas de danger.

Casat, [عuzú]? No m'hi veurà [pá]. (24:04)

The personal pronoun jo ('I'), usually pronounced [ḑó], [ḑó] or [jó] has been changed into [عuzú]. It looks like $\mathrm{eu}$ - has been added to jo. There is only an example where the form jo has been used. 
With regard to the reflexive pronouns, variation has been detected in first and second person singular (26-28).

(26) T'entends [kef] que j'te dis?

Que no [mi] [ Séns] el que [ti] dic? (26:47)

(27) Ah, quand même, [ $\mathrm{Se}]$ pas trop tôt.

[mi] pensava que no mi ho diria. (28:51)

(28) Imagine-toi muté dans le [ $\left.\int y d\right]$ et qu'on t'parle comme tu l'as fait là, hein?

Imagina-[ti] que [ti] enviessin al [Jud] i [ti] parlessin així. $(37: 49)$

It could look like the Catalan forms me and te have been used, instead of the more frequent $\mathrm{em}$ and $\mathrm{et}$, and that a vocalic shift has been applied afterwards but the fact is that these are the forms used in the ST (29-30).

(29) Marié, [mi]? Y a pas de danger.

Casat, [عuzú]? No m'hi veurà [pá]. (24:04)

(30) On dit pas [mwa], on dit [mi]. Et on dit pas [twa], on dit [ti]. No es diu [mə], es diu [mi], I en lloc de [tə] es diu [ti]. (41:42)

Moi and toi are pronounced [mi] and [ti] by some Chti characters.

In the determiners, the singular and plural forms of the definite article el and els are changed into eule and eules (31-33).

(31) [ [e] juste au-dessus, votre logement de [fõk $\left.\int j \tilde{o}\right]$, au d'sus [dœel] poste.

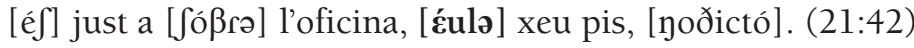

(32) Les meubles.

[ع́uləs] mobles. (22:41)

(33) Euh, un tabouret.

[Éulə] tamboret. (38:42)

Notice that the prefix which has been added is similar to the previous examples (31-33). [œ1] is the Chti form in the ST (34-35).

(34) Respirez par [œel] bouche, [ $\left.\int \mathrm{j}\right]$ va aérer.

Respiri [pélə] boca, [sí] [Jajrəzará]. (29:10)

(35) Et il aime pas les frites [ol] [buburs] ?

Què no ha vingut? No li [grádən] les patates, al teu [bußúrs]? $(37: 01)$ 
The present simple form of haver ('to have') he has also been modified.

(36) J'vous ai reconnu à vot' plaque qu'est treize. [i $\mathrm{j} i][\mathrm{je}]$ cinquante-neuf.

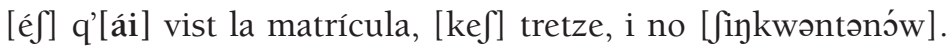
(21:08)

The form [ái] is a way to pronounce [átf] in some Catalan varieties, and is widely used in spoken Catalan.

Finally, forms res and re ('nothing') are perfectly correct in Catalan although $r e$ is the one that has been used (37-38).

(37) Mais vous n'avez vu [Rja], [Rja], [Rja].

Però re, re, re. (21:14)

(38) $\left[\int a\right]$ veut $[\mathbf{R j a}]$ dire, je...

No vol dir re, ves. (41:07)

The reason could be that re may be more frequent in spoken Catalan.

\subsubsection{Syntactic Level}

The syntactic level has some particularities (39-41).

(39) Parce que j'parle ch'timi, [ $\mathrm{je}][\mathrm{Ja}]$.

Sí, perquè parlo xetí, ves. (21:35)

(40) Marié, [mi]? Y a pas de danger.

Casat, [cuzú]? No m'hi veurà [pá]. (24:04)

(41) Faut pas qu'on [fafe] trop de bruit.

No fem [pá] gaire [xuró $\operatorname{~].~(24:24)~}$

Sentence order has been changed, so the elements are not in the canonical order to emulate the spoken language, where this is very common. Expressions with ves and pas (pronounced [pá] instead of [pás]) have been widely used as discursive markers among others like au and doncs.

\subsubsection{Lexical-semantic level}

The general phenomena that have been observed in this level are loanwords from the ST, vocabulary taken from Catalan varieties (or at least the ones that are less common in some Catalan varieties) and constructed words (a lesser used strategy). 
(42) No, no, j'ai [Rja], [vẽ̃us]!

No, i ara, [ßəndəðús]! (21:30)

(43) Et il aime pas les frites [œl] [buburs]?

Què no ha vingut? No li [gráðən] les patates, al teu [ßußúrs]?

(37:01)

(44) Mais on dit pas «merde», on dit [dybrõe].

Donques, no diem "merda", diem [dibrén]. (41:22)

(45) On dit pas «bordel», on dit [miKar].

I no diem "collons", sinó [miKár]. (41:33)

The examples above include some loanwords used in the TT. Their pronunciation has been adapted to similar sounds in Catalan when necessary. Synchrony reasons may have motivated this decision.

Finally there are some constructed words but only a small number of them have been noticed:

(46) Quo qu't'[af] dans t'tête?

On [kərátfu] tens [Éulə] cap? (31:31)

«[kərátfu]» is a constructed word from the Catalan carai ([kərái]), an euphemism used to express displeasure.

\subsection{Spanish ${ }^{12}$}

\subsubsection{Prosodic Level}

In the Spanish dubbing phonetic shifts are much less frequent than in the Catalan translation, in which they are the most used resource in recreating the constructed linguistic variation. In the Spanish dubbing, consonantal shifts and elisions have been noticed. As in the Catalan translation, the variation tends to be systematic with some trifling exceptions.

With regard to the consonantal shifts, as it has also been mentioned in the Catalan dubbing, the most iconic one is replacing [s] with [ $\int$ ] because it is the most audible feature of Chti. However, in most cases in the Spanish dubbing, this sound is not always [ $\left.\int\right]$, but [t $]$.

According to RAE's Ortografía de la lengua española (2010: 25), the /J/ phoneme does not exist in modern Spanish. However, it existed in the evolution

12. Given that no morphological or syntactic variation marks have been observed in the Spanish dubbing, these categories have been left out from the analysis. 
process from Latin to Romance but it disappeared as well as other voiced and unvoiced fricative sounds.

In the dubbing, [s] is always replaced with $[\mathrm{f}]$ or $[\mathfrak{t}]$, and in some cases $[\theta]$ is also replaced by $\left[\int\right]$.

(47) [ [e] juste au-dessus, votre logement de [fõkfjõ], au d'sus [dœl] poste.

Ahí [eftá] [Ju] vivienda [ofifiál], sobre la [ofifína]. (21:43)

(48) Bonne nuit, [mejjø] le Directeur.

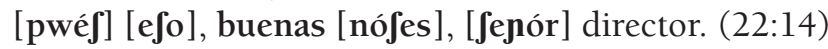

In examples 47 and 48 , the [s] or [ $\theta$ ] phonemes have been replaced by [S] in several words, such as está, su, oficial, oficina, pues, eso and se. There is one exception (48), in which $\left[\int\right]$ replaces [t] $]$ in noches ('night'). Sometimes the sound $[\theta]$ has also been replaced by $[s]$ :

(49) Lui, j'te dis qu'[ $[$ et] un drôle. Il va nous foutre [œl] brun.

Pues yo te digo que es un listo, nos va a [asér] la puñeta. (31:

13)

(50) Quo qu't'[af] dans t'tête? ¿Dónde tienes la [kaßésa]? (31:31)

(51) T'as pas besoin de dépenser tes sous pour [Rja]. ¿Y qué [nesesiðáð] tienes de hacer esas [tontás]? (31:40)

(52) Ferme [œt] grif, [œt] langue va être usée qu'tes bras seront encore neufs!

[sjéra] el pico, que tienes la lengua gastada y los [brásos] como nuevos. (31:52)

In (49)-(52), [s] replaces [ $\theta$ ] in different words and positions. However, this shift has not been applied to the whole Chti speech. There is one case in which [S] plays an important role:

(53) J'ai mal à $[m \tilde{\varepsilon}][$ tyy]. C'est tout. Me duele el [jul] [namás]. Me duele el [jul]. (21:23)

(54) Je suis tombé sur [mi] [ty $[\mathrm{ky}]$. Me he caído de [Jul]. (21:24)

(55) "Le [tfy] ?" Voilà, c'est pas [terib] comme vous parlez. ¿El [Ju]? Esto no tiene buena pinta. (21:25)

In the Spanish dubbing, the loanword cul ([ky], 'bottom') can be found pronounced in the Chti way [tyy]. Unlike the Catalan dubbing, the shift has been 
applied to a loanword from the ST instead of using a Spanish word. In the dubbing, the word cul is pronounced either [ $\left.\int \mathrm{ul}\right]$ or [ $\left.\mathrm{Ju}\right]$.

Regarding elisions, they have also been noticed in the Spanish dubbing:

(56) J'vous ai reconnu à vot' plaque qu'est treize. [i $\mathrm{i} i]$ [ $\mathrm{e}]$ cinquanteneuf. J'vous ai fait signe d'arretêr vot' carète. Mais vous n'avez vu [Rja], [rja], [Rja].

[rekono $\int i ́$ [ [ u $]$ matrícula que pone trece y aquí [e] cincuenta y nueve. [lí⿴e] [Jénas] para que agarrara el carro pero no me vio. [toi] bien, no tengo nada, no tengo [na], [na], [na]. (21:12)

(57) Mais j'ai jamais dit [ja].

No he dicho [naðéjo]. (22:55)

(58) Au fond, y a la [Jal] de bains, y a tout ce qu'il faut.

Ahí [ta] el baño, con [to] lo necesario. (24:16)

The first syllable of the conjugated forms of the verb estar ('to be'), in (56)(58), estoy and está, has been left out and shortened into [toi] and [ta]. Nada ('nothing') is pronounced [na] (56) and todo, [to] (58). All these elisions are frequent in spoken Spanish; some of them tend to lower the register in standard language contexts.

\subsubsection{Lexical-semantic Level}

Within the lexical level, only some examples of variation have been found:

(59) Un hôtel à Bergues à cette heure ? Oh [vẽðus] !

¿Un hotel en Bergues a estas horas? Oh jo, jo. ¡[bandjós]! (23:24)

(60) Salut, [tizót].

¿Qué hay, [tióte]? (29:47)

(61) Vous l'connaissez, l'aut' [buburs] avec [œl] moteur qu'a déposé Annabelle?

¿Conocéis a ese motero [boßéras] que ha traído a Annabelle? $(31: 24)$

(62) Ben, à la baraque à frites.

A la barraca de las [papas]. (34:27)

In (59), [bandjós] is an adaptation of the French word used in the ST, vindiouce ([vẽðus], shortened from vingt de diousse), that seems to sound more Spanish, as the word diós ('god') can be clearly recognized. In (60) [tióte], a variation of tío ('dude'), has been used as a colloquial vocative form. [boßéras] (61) is 
a normative word that means 'nonsense', but here it should be regarded as a variation of bobo ([boßo], 'silly'); in the ST the word boubourse ([buburs]) is a Chti form that duplicates the first syllable of bourse ('pocket'); their similarity is appropriate for a good labial synchrony. Finally papa is a Spanish variation for patata ('potato').

\section{Subtitles}

\subsection{Catalan $^{13}$}

\subsubsection{Prosodic Level}

In the subtitles, as in the dubbing, three different kinds of phonetic shifts (expressed through spelling) have been noticed - vowels, consonants and elisions. Regarding vowels, the same shifts applied to the dubbed version have been noticed in this modality:14

(63) Pac'que ch'est p't' être les chiens. (22:25)

Dòs que no els va dixar. (22:37)

(64) J'ai jamais dit cha. (22:41)

No he dit pa re, de quixar. (22:54)

(65) Je peux frimer aussi avec min vélo. (36:48)

Mira, jo també ho fai amb la bici. (37:06)

(66) -Cha va, M. Vasseur? (32:33)

-Comme un vu, min garchon. (32:35)

-Bon dia, 'nyor Vasseur, cum anem? (32:47)

—Cum un vell, ves. (32:49)

The vocalic shift in (63)-(64) is expressed reducing ei to $i$ in some verbs as deixar ('to let') and queixar-se ('to complain'). In (65) -aig has been reduced to -ai in the form faig ('I make') of the verb fer. Finally, in (66) there is another word that experiences a vocalic shift that is replacing $o$ with $u$.

In relation to consonants, there are only three main types of shifts, which are the same applied to the dubbing:

(67) -M. Bailleul ? (20:44)

—Ouais, ch'est mi. (20:45)

13. It must be pointed out that the Catalan subtitles are based on the Catalan dubbing. They seem to be a reduction of the dubbed version as a consequence of the modality restrictions.

14. See 5.1.1. 
-Senyor Bailleul? (20:56)

-Xí, jo mateix. (20:59)

(68) J'vous ai reconnu à vot' plaque. Ichi, ch'est 59. (20:56)

Éix qu'hai vist la matrícula, qu'éix tretze, i no xinquanta-nou.

(21:08)

(69) Faut pas qu'on fache trop de bruit. (24:09)

No fem pa gaire xoroll. (24:24)

The first one is replacing $s$ in initial or final position with $x$, what will be read as $\left[\int\right]$ or [ $\left.\mathfrak{d}\right]$ by Catalan speakers. In most cases, however, this is not a systematic shift that affects every word:

(70) J'ai mal à min tchu. Chuis tombé sur min tchu, quo. (21:10)

Només mi fa mal el xul i prou. (21:24)

(71) Vot' logement de fonkchion est au-desus de l'poste. (21:31)

Éix just a xobre l'oficina, eule xeu pis, 'nyor di'ctor. (21:42)

(72) Pac'que ch'est p't' être les chiens. (22:25)

Dòs que no els va dixar. (22:37)

Since replacing $s$ with $x$ in every subtitle may complicate reading comprehension, it may be an intentional gesture.

The second one consists in replacing $c$ with $x$ in a specific word $-c u l$ ('bottom'):

(73) J'ai mal à min tchu. (21:10)

Només mi fa mal el xul i prou. (21:24)

(74) Chuis tombé sur min tchu, quo. (21:10)

Éix qu'hi caigut de xul. (21:24)

The similarity between French and Catalan facilitates the recreation of the humorous effect in the TT and the spelling shifts are readable in both ST and TT. In the ST the word cul has been written as tchu emulating the Chti pronunciation $[\mathrm{t} y \mathrm{y}]$.

And finally, a minor shift has been noticed. Replacing ix with $c$ in això ('this') and aixi ('this way'). Both forms are widely used in Catalan, but açò is written in a normative form and açí is not; the normative one would be ací. This orthographic transgression could be considered as eye dialect,,$^{15}$ a strategy impossible to use in dubbing modality.

15. McArthur (2003) states that this is a term first used by George P. Krapp in The English Language in America (1925) "for how colloquial usage appears in print; spellings in 
(75) Les chiens, ch'est cha. (22:56)

Sí, dixar. Açò, açò. (23:09)

(76) On est chez m'mère. (23:56)

No, 'çó éix casa ma mare. (24:11)

(77) Respirez par eule bouche pour aérer. (28:53)

Respiri pela boca, 'çí x'airejarà. (29:11)

With regard to elisions, which have been indicated using an apostrophe, these are also a resource much used in the subtitles. Most of the elisions are a transcription of the dubbing. It is worth mentioning that there are a higher number of elisions than in the Spanish subtitles.

One of the most noticeable ones is eliding $a$ or $e$ (both representing [ə]) at the beginning of some conjugated verb forms as anar ('to go'), agafar ('to take'), agradar ('to like') or enamorar ('to fall in love').

(78) Faut vite aller se coucher, alors. Ch'est là-haut. (23:38)

Ah, donques 'nem directe al llit. Éix dalt. (23:53)

(79) Au fond, y a la challe de bains. (24:00)

I al fons hi ha eule bany, 'gafi el que convingui. (24:16)

(80) Vous devez aimer l' lavande ! (24:40)

Li deu 'gradar l'espígol, a vostè qu'éix del xud. (24:56)

(81) On t'a pas appris à dire merchi, din tin pays ? (37:26)

Vaja, qu'allà baix no li han 'senyat a dir gràcies, o què passa?

(37:42)

(82) T'avo peur que j'tombe amoureux ? (37:11)

No xé de què tenia por, de que mi 'namorés? (37:28)

(83) On a tous donné un p'tit quequ'chose pour vous meubler là-haut.

(38:15)

Hem pogut 'replegar quatre mobles perquè els posi al xeu pis.

(38:30)

There are other types of elision at the beginning or within some words but only in specific cases of single words or word combinations.

(84) Bienvenue, M. le directeur (20:43)

Benvingut, 'nyor di'ctor. (20:57)

which 'the convention violated is one of the eyes, not of the ear'”. Määttä (2004: 320) and Ramos Pinto (2009: 302) use this concept in their works. 
(85) Bon ben... Bonne nui, M. le directeur. (22:00)

$\mathrm{Au}$, doncs, bona nit, 'nyor di'ctor. I... fins demà. (22:14)

(86) Bon be... Bonne nuit, M. le directeur. (22.00)

Escolti, qu'éix l'hora. 'Nyor Abrams, x'ha de llevar. (25:55)

(87) M. Abrams, faut vous réveiller. (25:40)

Qu'éix eule nou di'ctor, dona. (26:55)

(88) Ch'est pas une raison, Antoine. (26:39)

El convido a dormir a ca meva i al 'nyor espavilat no xe li acut re més que travar la porta amb una caillèle. (37:22)

The examples above show elision in the word 'nyor (senyor, 'sir') and also when this is combined with another word with elision - di'ctor ('director'), as in the dubbing. The high number of elisions in the ST is also remarkable.

Regarding elisions in word contact, much more frequent in the Catalan subtitles than in the Spanish ones, there is an elision in teva ('your' in feminine singular form) and in the constructed definite article eule $e^{16}$ when they are followed by a vowel:

(89) Pourquo qu'il dort dans t'chambre, ch'ti là ? (26:18)

I per què ha dormit a la te'bitació? No éix la teva? (26:35)

(90) Pour un mois d'avril, fait même ko. (29:07)

Per xer eule'bril, fa calor i tot. (29:23)

In example 89 la teva habitació ('your bedroom') has been shortened into la te'bitació, which means that there is an elision in both words. Example 90 is different because there is an elision only in the second word: eule abril ('April') has been changed into eule'bril. Even though elisions are very common in oral Catalan, in standard, substandard and dialects, this is an example of constructed elision specially.

However, real oral Catalan elisions have been transcribed and used in the dubbing and subtitles.

(91) J'vous ai reconnu à vot' plaque. Ichi, ch'est 59. (20:56)

Éix qu'hai vist la matrícula, qu'éix tres, i no xinquanta-nou. (21:08)

(92) Cha va! Tu manges avec eute bouc, pas avec tin dos. (38:59) $\mathrm{Au}$, va, home. Qu'es menja amb la boca i no amb l'esquena. $(39: 15)$

16. See 6.1.2. 
(93) Cha chent bon quand on a son nez d'dans. (24:48)

Fan tan bon'ulor, quan hi fiques eule nas. (25:04)

(94) Antoine, ch'est pas un mauvais bougre. (37:56)

El conec de fa molt temps, l'Antoine, éix un bon jan, la v'ritat.

(38:12)

(95) Vous lui mettez pas l'avertissement, hein ? (38:07)

No l'amonestarà, oi, per'xò? (38:24)

(96) Regardez! (38:24)

Miri'çò. (38:38)

(97) Respirez par eule bouche pour aérer. (28:53)

Respiri pela boca, 'çí x'airejarà. (29:11)

Que ('that') is one of the most frequent words elided due to the vocalic contact with the word that follows - que éix, que hai and que es become quéix, $q u$ 'hai and qu'es. The elision in the word contact bon'ulor (bona olor, 'plesant smell') and in the pronunciation veritat ( $v^{\prime} r i t a t$, 'truth') are also very common in spoken Catalan and therefore they have been represented in the subtitles. Other elisions that can be observed are the shift of per això, miri això and per la into per'xò, miri'çò ${ }^{17}$ and pela respectively. The examples of elisions above are widely used in oral Catalan, but not in written contexts, even though they are perfectly understandable and can be seen in constructed orality but usually to a lesser extent.

\subsubsection{Morphological Level}

The highest number of phenomena in this level is related to the personal pronouns:

(98) Chuis un peu déçu, quand même. (38:42)

Eujo m'hi quedat una mica trist. (38:56)

(99) J'parle ch'timi. (21:26)

Parlo xetimí, eujo. (21:37)

(100) $\mathrm{Mi}$ ? Y a pas de danger. (23:47)

Casat, eujo? No m'hi veurà pa. (24:04)

As the examples above illustrate, the personal pronoun jo ('I') has been changed into eujo. A prefix ${ }^{18}$ has been added to the Catalan form as in the dubbing. The

17. In the subtitles there are orthographical differences between per'xo and miri'çò; the standard orthography is això.

18. This prefix is added to the definite article in the ST. 
only difference between the two modalities here is that a Catalan speaker will

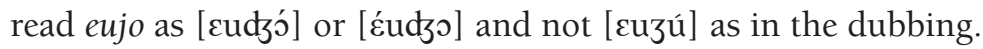

Regarding the reflexive pronouns of first and second person singular, variation has also been found.

(101) Ch'est pas trop tôt. (28:33)

Mi pensava que no mi ho diria. (28:51)

(102) T'entends qu'ech que j'te dis ? (26:29)

Que no mi xents el que ti dic? (26:47)

(103) Imagine-toi dans de Chud et qu'on t'parle comme ça, hein? $(37: 34)$

Imagina-ti que ti enviessin al xud i ti parlessin així. (37:49)

In the Catalan subtitles, as in the dubbing, the TT forms $m i$ and $t i$ are used to emulate the ST:

(104) On dit pas moi, on dit mi. Et on dit pas toi, on dit ti. (41:28)

No es diu me, es diu mi. I en lloc de te es diu ti. (41:42)

With regard to the determiners, singular and plural forms of the definite article $e l$ and els have been changed into eule and eules:

(105) Au fond, y a la challe de bains. (24:00)

I al fons hi ha eule bany. (22:16)

(106) Les meubes. (22:29)

Eules mobles. (22:50)

(107) Ch'est du maroilles. (27:39)

Éix el Maroille, ves. (27:56)

(108) J'ai mal à min tchu. Chuis tombé sur min tchu, quo. (21:10)

Només mi fa mal el xul i prou. (21:24)

Notice that the prefix that has been added is the same as in the previous examples (98)-(100). In this case we can also talk of emulation. Eules will be read as pronounced in the dubbing. The present simple form of haber ('to have') he has also been modified:

(109) J'vous ai reconnu à vot' plaque. Ichi, ch'est 59. (20:56)

Éix qu'hai vist la matrícula, quéix tres, i no xinquanta-nou. (21:08) 
As has been pointed out, the form hai is a feature of some Catalan varieties widely used orally. Both res and re ('nothing') are real forms in Catalan, but in the subtitles only re has been used:

(108) Cha va, cha va. (20:51)

No. No éix re. (21:03)

(107) Ça veut rien a dire. (40:54)

No vol dir re, ves. (41:07)

The reason could be that re may be more frequent in spoken Catalan and, as the subtitles emulate the dialogues between characters, it has been preferred.

\subsubsection{Syntactic Level}

The syntactic level has certain particular features (108-110).

(108) Parc' que j'parle ch'ti, ch'est cha ? (21:23)

Sí, perquè parlo xetí, ves. (21:35)

(109) $\mathrm{Mi}$ ? Y a pas de danger. (23:47)

Casat, eujo? No m'hi veurà pa. (24:04)

(110) Faut pas qu'on fache trop de bruit. (24:09)

No fem pa gaire xoroll. (24:24)

As mentioned, the sentence order is not the canonical one because it imitates the orality. Also in the subtitles, discursive markers such ves and pas alongside with $a u$ and doncs have been added. Pas has been written pa, imitating the French pronunciation.

\subsubsection{Lexico-semantic Level}

The general phenomena that have been observed in this level are loanwords from the ST, vocabulary taken from Catalan linguistic varieties (or less common in some Catalan varieties) and constructed words (less used strategy).

(111) Non. J'ai rin, vingt diousse. (21:18)

No, i ara, vingt de diousse! (21:30)

(112) Cha va, tizaute?

Hola, tizaute. (29:47)

(113) On dit pas "merde", on dit "du brun". (41:08)

Donques, no diem "merda", diem "du brun". (41:22) 
(114) Il est pas là, eul boubourse ? (36:45)

Què no ha vingut? No li 'graden les patates, al teu boubourse?

(37:01)

(115) Je l'invite à dormir à m'baraque, il voit des photos de nous au carnaval, et il bloque eule porte de chambre. (37:03)

El convido a dormir a ca meva i al 'nyor espavilat no xe li acut re més que travar la porta amb una caillèle. (37:22)

(116) On dit pas "bordel", mais "milliard". (41:18)

I no diem "collons", sinó "millard". (41:33)

In (111)-(116), the words in bold are some examples of loanwords from the ST. Regarding the orthography, it has not been changed in words like tizaute, boubourse and caillèle but it has in millard.. No italics have been used either.

\subsection{Spanish ${ }^{19}$}

\subsubsection{Prosodic Level}

There are two main features in this level - consonantal shifts and elisions. With regard to the first ones, ch has been used to represent [S], as in French, but a Castilian Spanish-speaker will read $[\mathfrak{g}]^{20}$ instead of $\left[\int\right]$ even though the ST will be audible at the same time.

(117) Bienvenue, M. le directeur (20:43)

Bienvenido, cheñor director. (20:56)

(118) Ouais, ch'est mi. (20:45)

Chí, choy yo. (20:59)

(119) Cha va, cha va. (20:51)

No pacha nada. (21:07)

(120) Vot' logement de fonkchion est au-desus de l'poste. (21:31)

Chu cacha echtá arriba, encima de correos. (21:43)

(121) Oh... bouguez pas. (24:20)

No se mueva. (24:36)

$S$ is replaced with ch unlike in the dubbing, where $[\mathfrak{g}]$ and $\left[\int\right]$ do not only replace $[s]$ but $[\theta]$. $S$ in final position has not been replaced in some instances.

19. While the Catalan subtitles are based in the Catalan dubbing, the Spanish subtitles differ from the Spanish dubbing because they have been carried out following different strategies. As in the dubbing, no morphological or syntactic marks have been noticed.

20. According to Ortografía de la lengua española, the graphical symbol ch represents $/ \mathbf{f} /$ (2010: 64). 
The shift seems systematic but there are few exceptions of no replacement as (121).

The orthography has been changed in the loanword cul ('bottom') using $k$ instead of $c$ and italics:

(122) Chuis tombé sur min tchu, quo. (21:10)

No. Chólo mi duele el kul, m'e caído de kul. (21:23)

(123) Le "tchu" ? Vous voulez pas qu'on aille montrer votre mâchoire à un médecin? (21:13)

¿El "kul"? Eso no está bien. ¿Quiere ver a un médico? (21:25)

In Spanish $c$ and $k$ represent the same sound, but $k$ is less frequent. It could be considered as eye dialect. There is also a one-off consonantal shift:

(124) Au, doncs, bona nit, 'nyor di'ctor. (22:14)

Buenas nokes, cheñor director. (22:14)

(125) J'vous ai fait signe d'arrêter vot' carète. Mais j'ai rin, j'ai rin. (50:59)

Le he hecho cheñas a chu coke y no m'ha visto. Estoy bon. (21:12)

It is replacing ch with $k$ in noches and coche. This shift can only be observed in one case after which it is not repeated. Regarding to elisions, they are much less frequent than in the Catalan subtitles (126-129).

(126) J'vous ai fait signe d'arrêter vot' carète. Mais j'ai rin, j'ai rin. (50:59)

Le he hecho cheñas a chu coke y no m'a visto. Estoy bon. (21:12)

(127) J'ai mal à min tchu. Chuis tombé sur min tchu, quo. (21:10)

No. Chólo mi duele el kul, m'e caído de kul. (21:23)

(128) J'ai jamais dit cha. (22:41)

No he dicho na d'eso. (22:55)

(129) Au fond, y a la challe de bains. (24:00)

Ahí 'ta el baño, con todo lo necesario. (24:16)

In (126)-(127) elisions can be observed between the first person singular pronoun me and the verb haber ('to have'). In (128) elisions are between the preposition de and the demonstrative pronoun eso. And in (129) the elision is in the first syllable of está. These are frequent oral features in Spanish. 


\subsubsection{Lexico-semantic level}

With regard to the lexical level, only a few examples of variation have been found (italics by the translator) (130-135).

(130) Vingt dieux ! (23:09)

¡Vandediós! (23:24)

(131) Ch'est ichi, m'baraque. (23:15)

Echta ech mi barraca. (23:29)

(132) Cha va, tizaute. (29:33)

Hola, tiarrón. (29:46)

(133) Vous l'connaissez, l'aut' boubourse qu'a déposé Annabelle? (31:08)

¿Conocéis a ese boborde que ha traído a Annabelle? (31:24)

(134) Bueno, en vez de "mierda", decimos churrán. (41:25)

On dit pas "merde", on dit "du brun". (41:08)

(135) ¡Coño! Es melarda. (41:33)

On dit pas "bordel" mais "milliard". (41:18)

In the examples above, vandediós (130) is another word adapted from the French form vingt diousse or vindiouce, in which the word diós ('god') can also be noticed, as in the dubbing. ${ }^{21}$ In (131), the word barraca ('shack') has been used instead of casa ('house') to emulate the French word baraque and a colloquial use. Tiarrón stands for 'dude' and it can be considered as a colloquial vocative in Spanish.

In (133) boborde is a constructed word from borde ('rude') for the ST word boubourse; both words duplicate the first syllable of another word. Finally, in the dinner scene, some swear words are explained, such as Spanish equivalents for du brun and milliard, churrán and melarda have been noticed. These constructed words remind of churro ('washout') and mierda ('shit').

\section{Conclusions}

Regarding translation strategies, a constructed dialect (option 2 according to Czennia 2004: 509-510) ${ }^{22}$ has been used in Catalan and Spanish dubbing and subtitles, creating a marked text that transgresses the norm and contains artificial marks, in line with Marco's (2002: 81) point of view, and Hatim and

21. 5.1.4.

22. See 4.1. 
Mason's recommendation (1990). Omitting any type of variation in the TTs was impossible in this film because of its relationship with the plot.

This constructed dialect has been created including real and constructed (those inspired by the ST) variation marks. They have been systematically applied to the TTs and the exceptions are so few that they do not constitute a tangible piece of evidence. Thus, they have mainly been omitted in the analysis. In addition, the jokes and misunderstandings that were transmitted through linguistic variation resources have been satisfactorily recreated in the TLs.

In the dubbing, what draws most attention in both TTs is the presence of phonetic shifts ${ }^{23}$ as they are one of the means of including linguistic variation in the dubbing. The decision to keep [S] and [t] could be motivated by the will to keep the "Chti sonority". The vocabulary is also striking — the loanwords (e.g. du brun, boubourse) in Catalan ${ }^{24}$ and the constructed words (e.g. boborde, churrán) in Spanish. Comprehension problems are not a concern, especially because in some scenes meanings are explained.

Presumably, in the dubbing, articulatory synchrony is one of the reasons for the strategies chosen, the result of which is a similar use of vocabulary to the one in the ST. Another reason could be the unwillingness to neutralize the text too much and lose its French-Chti origin. Marks included in the morphologic and syntactical levels have helped to bring the different parts of the constructed dialects together.

With regard to the subtitles, orthographical transgressions are the most prominent feature, regardless of the language level they are related to. In comparison with dubbing, however, subtitles may be slightly more difficult to understand by the TT audience because they may be generally more used to audible transgressions and less so to written ones. Some orthographic transgressions can be considered as eye dialect.

However, in this case both modalities may be difficult to understand when Chti first appears in the storyline, but the TT audience gradually improves their understanding and can relate to one of the main characters (Philippe Abrams).

According to Briguglia (2011: 145), the literary context of the TL must be taken into account when it comes to ST with linguistic variation marks. In other words, the literature of the TL must be analyzed in search of literary texts with linguistic variation marks. If there are literary works with this

23. In the prosodic level, a higher number of transgressions has been noticed in the Catalan translation than in the Spanish one.

24. Discourse markers are remarkable too. 
characteristic, the TT reader is more likely to accept linguistic variation in translated texts and vice versa if linguistic variation is not present in the TL literary context.

This could be extended to the audiovisual context and analyze whether linguistic variation is common or not in the TL audiovisual context. In the Catalan and Spanish context, only few cases have been found. In Catalan, linguistic variation in contrast with standard can be found in TV series produced by TVC (Televisió de Catalunya), such as Lo Cartanyà (2005-2007) and Gran Nord (2012-2013), ${ }^{25}$ and also in films such as Pa negre (Villaronga 2010), which used different types of linguistic variation. According to Zabalbeascoa (2008: 171), linguistic variation is not very common in dubbing into Catalan and it is rarely used in original Catalan productions. In Spanish, examples of films like Solas (Zambrano 1999) and 7 vírgenes (Rodríguez 2005) have been found, but there is not a high number of such films either.

All this boils down to the fact that, even though linguistic variation is not very common in the Catalan and Spanish audiovisual contexts (neither in original versions nor in the translations), a constructed dialect is the main strategy used in translating this film. The result demonstrates how creating a constructed dialect mixing features from the SL and the TL can become a resourceful strategy.

\section{References}

BRIGUGLiA, Caterina. (2011) "El reto del dialecto: Il pasticciaccio de Gadda al español, al inglés y al catalán." Sendebar 22, pp. 137-158.

BRIL, Laurence. (2008) Le parler chti. Riom: De Borée.

BRUMME, Jenny. (2012) Traducir la voz ficticia. Berlin: De Gruyter.

CARTON, Fernand. (1990) "Areallinguistik I B - Nördliche Dialekte, Picardie". In: Holtus, Günter; Michael Metzeltin \& Christian Schmitt (eds.) 1990. Lexikon der Romanistischen Linguistik, 5:1. Tübingen: Niemeyer, pp. 605-615.

CATFORD, John Cunnison. (1965) Linguistic Theory of Translation: An essay in Applied Linguistics. London: Oxford University Press.

Chaume, Federic. (2003) Doblatge i subtitulació per a la TV. Vic: Eumo.

Chaume. (2004). Cine y traducción. Madrid: Cátedra.

CZENniA, Bärbel. (2004) "Dialektale und soziolektale Elemente als Übersetzungsproblem." HSK 26:1, pp. 505-512.

DaWson, Alain. (2008) "Bienvenue chez les Ch'tis: la langue opaque." Langues et cité 12, p. 4.

25. Its plot is similar to Bienvenue chez les Ch'tis. 
FUENTES, Adrián. (2001) La recepción del humor audiovisual traducido: estudio comparativo de fragmentos de las versiones doblada y subtitulada al español de la película Duck Soup, de los hermanos Marx. Granada: Universidad de Granada. Unpublished doctoral dissertation.

GREGORY, Michael. (1967) "Aspects of varieties differentiation." Journal of Linguistics 3:2, pp. 177-198.

Grosse, Sybille. (2010) "Bienvenue chez les Ch’tis: estrategias de ficcionalización del contacto de lenguas y descripción lingüística." In: Andújar, Gemma \& Jenny Brumme (eds.) 2010. Construir, deconstruir y reconstruir: mímesis y traducción de la oralidad y la afectividad. Berlin: Frank \& Time, pp. 121-139.

HallidaY, Michael; Angus McIntosh \& Peter Strevens. (1964) The Linguistic Sciences and Language Teaching. London: Longman.

HATIM, Basil \& Ian MASON. (1990) Discourse and the translator. London: Longman. LAURIAN, Anne-Marie. (1989) "Humour et traduction au contact des cultures." Meta: Translators' Journal 34:1, pp. 5-14.

LAURIAN. (1992) "Possible/ Impossible Translation of Jokes." Humor: International Journal of Humor Research 5, pp. 111-127.

Leibold, Anne. (1989) "The Translation of Humor; Who Says it Can't Be Done?" Meta: Translators' Journal 34:1, pp. 109-111.

MÄÄтTÄ, Simo K. (2004) "The ideology of translation in The Sound and the Fury in French." Target 16:2, pp. 319-339.

McArthur, Tom. (2003) Concise Companion to the English Language. Oxford: Oxford University Press.

Manini, Luca. (1996) "Meaningful Literary Names: Their Forms and Functions, and their Translation." The Translator: Studies in Intercultural Communication 2, pp. 161-178.

MARCO, Josep. (2002) El fil d'Ariadna: Anàlisi estilística i traducció literària. Vic: Eumo.

MARTíNEZ SiERRA, José. (2008) Humor y traducción: Los Simpson cruzan la frontera. Castellón de la Plana: Universitat Jaume I.

MARTÍNEZ SiERRA. (2015) "Una aproximació descriptiva als aspectes restrictius del doblatge de l'humor." Translation Journal 18:4.

MAYORAL, Roberto. (1999) La traducción de la variación lingüística. Soria: Monográficos de la Revista Hermeneus.

MuÑoz MARTín, Ricardo. (1995) Lingüística para traducir. Barcelona: Teide.

NASH, Walter. (1985) The Language of Humor. London/New York: Longman.

RABADÁN, Rosa. (1991) Equivalencia y traducción: problemática de la equivalencia translémica inglés-español. León: Universidad de León.

RAmos Pinto, Sara. (2009) "How important is the way you say it? A discussion on the translation of linguistic varieties." Target 21:2, pp. 289-307. 
Real Academia Española. (2010) Ortografía de la lengua española. Madrid: Espasa-Calpe.

Reutner, Ursula. (2013) Bienvenue chez les Ch'tis: Scénario et dialogues de Dany Boon, Franck Magnier et Alexandre Charlot, d'après une idée originale de Dany Boon. Stuttgart: Reclam.

Tello Fons, Isabel. (2011) La traducción del dialecto: análisis descriptivo del dialecto geográfico y social en un corpus de novelas en lengua inglesa y su traducción al español. Castellón: Universitat Jaume I. Unpublished doctoral dissertation.

Whitman, Candace. (1992) Through the Dubbing Glass. New York: Peter Lang. ZABALBEASCOA, Patrick. (1996) "La traducción de la comedia televisiva: implicaciones teóricas." In: Bravo, José María \& Purificación Fernández Nistal (eds.) 1996. A Spectrum of Translation Studies. Valladolid: Universidad de Valladolid, pp. 173-201.

ZABALBEASCOA, Patrick. (2001) "La ambición y la subjetividad de una traducción desde un modelo de prioridades y restricciones." Traducción \& Comunicación 2, pp. 129-150.

ZabalbeascoA, Patrick. (2008) "La credibilidad de los diálogos traducidos para audiovisuales." In: Brumme, Jenny (ed.) 2008. La oralidad fingida: descripción y traducción. Teatro, cómic y medios audiovisuales. Madrid: Iberoamericana; Frankfurt am Main: Vervuert, pp. 157-175.

\section{BIONOTE / NOTA BIOGRÁFICA}

Eva Garcia-PInOS is a PhD student and a Predoctoral Researcher in the Translation and Language Sciences Department of the Universitat Pompeu Fabra (UPF), Barcelona. She holds a BA in Translation and Interpretation and a MA in Translation Studies, both from UPF. Her current research focuses on the role of the linguistic variation in translation, with special interest in literary and audiovisual texts. She also teaches Translation in the BA in Translation and Interpreting at UPF.

EVA GARCiA-PinOS és doctoranda i investigadora predoctoral en el Departament de Traducció i Ciències del Llenguatge de la Universitat Pompeu Fabra (UPF) de Barcelona. És graduada en Traducció i Interpretació i té un Màster en Estudis de Traducció, totes dues titulacions obtingudes a la UPF. Actualment realitza recerca sobre la funció de la variació lingüística en traducció, amb interès especial en textos literaris i audiovisuals. També realitza docència d'assignatures de traducció al Grau en Traducció i Interpretació de la UPF. 